\title{
Dampak Pelatihan Menjahit Terhadap Keterampilan Ibu-Ibu Rumah Tangga
}

\author{
Fadliyanto Ibrahim ${ }^{1}$, Misran Rahman ${ }^{2}$, Abdul Rahmat ${ }^{3}$ \\ Jurusan Pendidikan Luar Sekolah, Fakultas Ilmu Pendidikan, Universitas Negeri Gorontalo \\ fadliyantoibrahim02@gmail.com,misranrahman@ung.ac.id, abdulrahmat@ung.ac.id
}

Received: 19 Agustus 2020; Revised: 24 Agustus 2020; Accepted: 28 Desember 2020

\begin{abstract}
The purpose of this study was to determine the impact of a sewing course for housewives in Paris Village, Gorontalo Regency. Impact refers to the long-term benefits to society such as increased knowledge, production efficiency, environmental improvement, financial benefits and so on. To get the answers above, researchers used Qualitative methods of interviewing techniques that are descriptive of the results of interviews and documentation studies. This study shows that the impact of sewing training for housewives has an impact on the income sector of trainees, thereby increasing the income of their respective families and they can enter the workforce or open their own sewing business thereby reducing unemployment rates in the village of Paris.
\end{abstract}

Keywords: Impact of Tailoring Training Course, on the skills of housewives.

\begin{abstract}
ABSTRAK
Tujuan penelitian ini untuk mengetahui Dampak Kursus menjahit bagi Ibu-ibu rumah tangga di Desa Paris Kabupaten Gorontalo. Dampak mengacu pada manfaat jangka panjang terhadap masyarakat seperti peningkatan pengetahuan, efisiensi produksi, peningkatan lingkungan hidup, keuntungan finansial dan sebagainya. Untuk mendapatkan jawaban di atas, peneliti menggunakan metode Kualitatif teknik wawancara bersifat uraian dari hasil wawancara dan studi dokumentasi. Penelitian ini menunjukkan bahwa Dampak pelatihan menjahit bagi ibu-ibu rumah tangga berdampak kepada sektor pendapatan peserta pelatihan, sehinga menambah penghasilan keluarga mereka masing-masing dan mereka bisah memasuki dunia kerja atau membuka usaha menjahit mereka sendiri sehingga mengurangi angka penganguran di Desa Paris.
\end{abstract}

Kata Kunci: Dampak Pelatihan Kursus Menjahit, keterampilan Ibu-Ibu rumah tangga.

(C2020 Fadliyanto Ibrahim, Misran Rahman, AbdulRahmat Under the license CC BY-SA 4.0

\section{PENDAHULUAN}

Konsep pendidikan mengenal adanya tiga pendidikan yaitu Pendidikan formal, pendidikan informal, dan pendidikan nonformal sebagai dari continuing education dan lifelong education, ketiga-tiganya tidakdapat dipisahkan damtidak dapat berdiri sendiri. Ketiganya saling mengisi terutama dalam memenuhi kebutuhan belajar sepanjang hayat (selama masyarakat itu ada).

Undang-Undang Nomor 20 tahun 2003 tentang Sistem Pendidikan Nasional menggariskan bahwa satuan pendidikan adalah kelompok layanan pendidikan 
yang menyelenggarakan pendidikan pada jalur formal, nonformal, dan informal pada setiap jenjang dan jenis pendidikan.

Pendidikan nonformal merupakn kegiatan yang terorganisir dan sistematis yang diselenggarakan diluar subsistem pendidikan formal. Meskipun kesemua istilah tersebut memiliki perbedaan dan kesamaan dengan pendidikan nonformal. Menurut Hamojoyo (1973: 7) pendidikan nonformal adalah usaha yang terorganisir secara sistematis dan kontintu diluar sistem persekolahan, melalui hubungan sosial untuk membimbing individu, kelompok dan masyarakat agar memiliki sikap dan cita-cita sosial (yang efektif) guna meningkatkan taraf hidup dibidang materi, sosial dan mental dalam rangka usaha mewujutkan lesejahteraan sosial.

Secara luas menurut Coombs (2006: 11) memberikan rumusan tentang pendidikan nonformal adalah: setiap kegiatan pendidikan yang terorganisasi, diselenggarakan di luar pendidikan persekolahan, diselenggarakan secara tersendiri atau merupakan bagian penting dari suatu kegiatan yang lebih luas dangan maksud memberikan layanan khusus kepada warga belajar didalam mencapai tujuan belajar.

Pendidikan formal adalah jalur pendidikan yang terstruktur dan berjenjang terdiri atas pendidikan dasar, pendidikan menengah dan pendidikan tinggi. Pendidikan nonformal adalah jalur pendidikan diluar pendidikan formal yang dapat dilaksanakan secara terstruktur dan berjenjang, sedangkan pendidikan informal adalah jalur pendidikan keluarga dan lingkungan (Sutarto, 2007: 1-2).

Kemampuan warga negara suatu negara, untuk hidup berguna dan bermakna serta mampu mengantisipasi perkembangan, perubahan masa depannya, memerlukan pembekalan ilmu pengetahuan, teknologi dan seni (IPTEK) yang berlandaskan nilai-nilai keagamaan dan nilai-nilai budaya bangsa (Subagyo, 2006: 1). Pendidikan yang baik dan bermakna adalah pendidikan yang mampu mengantarkan dan memberdayakan potensi anak didik sesuai dengan bakat, minat, dan kemampuan yang dimilikinya dan pada akhirnya akan menjadi bekal dimasa depan, bukan semata-mata untuk mengejar target lulus ujian tetapi 
pendidikan juga harus mampu membekali remaja atau anak dalam menghadapi problem kehidupan juga dunia kerja.

Kesulitan dan tantangan dalam kehidupan manusia baik yang diakibatkan oleh lingkungan maupun alam yang kurang bersahabat, sering memaksa manusia untuk mencari cara yang memungkinkan mereka untuk keluar dari kesulitan yang dialaminya. Masyarakat Indonesia banyak yang tidak melanjutkan pendidikan ke taraf yang memungkinkan dan mereka lalu menggeluti profesi tertentu, menuntut upaya-upaya untuk membantu mereka dalam mewujudkan potensi yang dimilikinya agar dapat bermanfaat bagi pembangunan bangsa.

Sejauh ini, anggaran yang berkaitan dengan pendidikan mereka masih terbatas, sehingga berbagai upaya untuk dapat terus mendorong keterlibatan masyarakat dalam membangun pendidikan terus dilakukan oleh pemerintah.

Hal ini dimaksudkan agar makin tumbuh kesadaran akan pentingnya pendidikan dan mendorong masyarakat untuk terus berpartisipasi aktif di dalamnya. Indonesia telah meluluskan jutaan siswa, tetapi tidak semuanya mampu melanjutkan pendidikan tinggi atau siap kerja karena terbatasnya skill yang dibutuhkan dunia kerja. Kenyataan yang ada diIndonesia tersebut, maka pendidikan nonformal mutlak dibutuhkan.

Antara pendidikan formal dan pendidikan nonformal telah saling melengkapi. Out put pendidikan formal (sekolah) dari berbagai jenjang yang kurang memiliki keterampilan, sebagian dapat dilengkapi dengan keterampilan untuk dapat bekerja pada instansi negeri dan swasta, atau mengembangkan usaha mandiri (wirausaha). Siswa yang putus sekolah dan tidak sempat mengikuti pendidikan formal diberikan kesempatan untuk mengikuti pendidikan nonformal (program pendidikan life skill) sehingga mampu meningkatkan taraf hidupnya. Salah satu dari sekian banyaknya jenis pendidikan nonformal yang ada adalah Lembaga Pelatihan dan Kursus (LPK).

Salah satu kursus yang cukup diminati masyarakat adalah kursus menjahit. Kursus ini mampu menjawab kebutuhan masyarakat dalam industri pakaian,mengingat bahwa saat ini iklim industri konveksi semakin meningkat dan 
permintaan pasar konveksi semakin besar sehingga perusahaan banyakmembutuhkan tenaga buruh jahit untuk memenuhi permintaan pasar.

Perkembangan itu terus menuntut penciptaan berbagai mode pakaian sehingga pakaian menjadi industri yang cukup diperhitungkan. Oleh karena itu, kursus menjahit harus mempersiapkan tenaga ahli bidang busana yang memiliki pengetahuan, sikap, keterampilan, dan bertanggung jawab dalam pembuatan busana sesuai dengan tujuan kursus yang menghasilkan sumber daya manusia yang mengerti prinsip-prinsip dasar menjahit pakaian/tata busana dan mengaplikasikannya secara praktis untuk para konsumen dalam rangka memenuhi kebutuhan industri busana. Berkaitan dengan hal tersebut, maka dibuat standar kompetensi lulusan minimal dibidang keterampilan menjahit pakaian, yang diharapkan mempunyai asas keterpakaian dan berguna dimasyarakat umumnya, sehingga hasil lulusannya dapat dipertanggungjawabkan dan mempunyai daya saing dan daya jual yang tinggi dimasyarakat secara profesional.

Berdasarkan kenyataan tersebut, maka program/kegiatan menjahit harus terus diperluas sesuai dengan kebutuhan dan kondisi perkembangan masyarakat. Kamil (2009: 54) menjelaskan bahwa: Konsep pendidikan non formal dalam kerangka pembangunan masyarakat dapat dilihat dari dua sisi peran, pertama masyarakat sebagai sumber daya pembelajaran, dan kedua masyarakat sebagai sasaran pembelajaran. Peran masyarakat sebagai sumber daya pembelajaran dapat dilihat dari daya dukung terhadap implementasi, pengelolaan, dan pengembangan programdi masa depan. Sedangkan peran masyarakat sebagai sasaran, dapat dilihatdari tingkat partisipasinya dalam berbagai program non formal yang berhubungan dengan peningkatan kemampuan, keterampilan, dan kualitas dirinya. Tingkat partisipasi peserta didik pada kursus menjahit sangat diharapkan dapat terealisasikan melalui proses pembelajaran yang menggunakan pendekatan andragogi (pendidikan orang dewasa) dan pendekatan partisipasif. Makna dari pendekatan ini adalah bahwa dalam pelaksanaan pembelajaran yang sasarannya orang dewasa yaitu pada peserta kursus diasumsikan sebagai orang yang telah memiliki konsep diri, pengalaman, kesiapan dan orientasi belajar sehingga mereka dilibatkan dalam setiap tahapan kegiatan, mulai dari perencanaan, pelaksanaan, 
dan penilaian. Hal ini sejalan dengan pendapat Sudjana (2000: 57) yang mengatakan bahwa: "Pembelajaran partisipatif bukan sekedar mengkondisikan peserta didik menjadi aktif, tetapi lebih dari itu ia mengkondisikan peserta didik terlibat langsung dalam kegiatan merencanakan, melaksanakan, dan menilai proses pembelajaran".

Data dampak pelatihan di indonesia yang di ambil dari Beberapa instansi di Indonesia termasuk juga dari Bank Indonesia, Kementrian kehutanan, BPPK, dan Kementrian Agama. Data dari bulan Januari sampai Desember 2017 yaitu: Peserta pelatihan merasa tidak puas atas adanya pelatihan sebesar $43 \%$, sedangkan $54 \%$ peserta pelatihan merasa puas, satu sampai dua persen merasa kurang puas atas adanya pelatihan yang mereka lakukan dan tidak sesuai minat dan bakat mereka sendiri.

Menurut Mathis (2002; 5) bahwa konsep pelatihan adalah suatu proses dimana orang-orang mencapai kemampuan tertentu untuk membantu mencapai tujuan organisasi. Oleh karena itu, proses ini terikat dengan berbagai tujuan organisasi, pelatihan dapat dipandang secara sempit maupun luas. Secara terbatas, pelatihan menyediakan para pegawai dengan pengetahuan yang spesifik dan dapat diketahui serta keterampilan yang digunakan dalam pekerjaan mereka saat ini.

Sejalan dengan tujuan pendidikan luar sekolah maka tujuan penyelenggaraan kursus menurut Sihombing (2001: 89).adalah:

1. Memperluas keikutsertaan masyarakat dalam pemerataan kesempatan belajar

2. Meningkatkan mutu masyarakat melalui pendidikan

3. Meningkatkan proses belajar mengajar untuk mencapai daya guna dan hasil yang optimal

4. Mempersiapkan warga belajar untuk mengembangkan diri pribadinya atau untuk memperoleh kesempatan kerja yang lebih besar.

Menurut Ruslin dan Mohamad (2017: 50-51) Dampak pada hasil belajar yang ditandai oleh banyaknya peserta didik lulusan pembelajaran Life skill yang memulai usaha kecil-kecilan dengan menekuni saah satu kegiatan usaha dari beberapa keteramilan yang telah dibelajarkan melalui program live skill. 


\section{METODE}

Penelitian ini menggunakan jenis penelitian kualitatif yang bersifat Interpretatif yaitu berusaha untuk mendapatkan data secara deskriptif dalam bentuk gejala tingkah laku dari orang yang diamati. Peneliti dalam penelitian ini memiliki peran sebagai instrument utama dalam penelitian yang diselenggarakan di Desa Paris Kabupaten Gorontalo untuk pengambilan data secara komprehensif.

Kehadiran peneliti dilokasi penelitian sangat penting untuk diketahui oleh informan, hal ini dimaksudkan untuk mempermudah mendapatkan data yang dibutuhkan, peran peneliti sebagai pelaku dalam penelitian yang harus beradabtasi dengan kondisi yang ada, dimana peneliti merupakan pengamat artinya peneliti terlibat secara langsung dilapangan dengan tujuan untuk mengumpulkan data yang benar-benar dibutuhkan dalm penelitian ini. dalam penelitian ini peneliti mengambil lokasi Desa Paris Kabupaten Gorontalo. Hal ini didasarkan atas pertimbangan bahwa lokasi penelitian tersebut berada diwilayah tempat tinggal peneliti serta memenuhi syarat terutama dalam hubungan dengan pengumpulan data penelitian. Karena di Desa Paris Kabupaten Gorontalo dapat menghasilkan nilai tambah Sumber Data. Dalam rangka pengumpulan data peneliti menggunakan prosedur observasi dan wawancara.

\section{HASIL DAN PEMBAHASAN}

\section{Hasil}

Berdasarkan hasil observasi ada sebagian warga belajar sudah tau menjahit dan pernah belajar secara otodidak dan ada juga sudah pernah mengikuti kursus menjahit di desa sebelah sebelumnya ada peserta pelatihan yang pindah kependudukaan dari Desa Tolangohula ke Desa Paris, namun ada dari peserta pelatihan sudah membuka usaha sendiri. Peserta pelatihan juga sudah paham dari apa yang di ajarkan oleh pelatih atau instruktur sehingga mereka menjahit sendiri tanpa di dampingi oleh pelatih. Ada beberapa keterampilan menjahit yang di ajarkan kepada peserta pelatihan menjahit yaitu pelayaan pelanggan, menggambar busana, mengukur tubuh pelanggan sesuai SOP, mengambar pola dasar, dan keuntungan fnansial. 


\section{Pembahasan}

\section{Pelayaan Pelanggan}

Dari hasil penelitian peserta kursus menjahit diajarkan cara melayanani kepada pelanggan, pelanggan merupakan salah satu unsur terpenting dalam komonikasih antara penjahit dan konsumen. Pelayanan kepada pelanggan bertujuan memelihara dan meningkatkan hubungan penjahit dan konsumen serta memantau berbagai keluhan pelanggan serta mengetahuai kebutuhan dan keinginan pelanggan serta menempatkan orientasi kepada memenuhan kepuasan pelanggan sebagai tugas utama.

\section{Menggambar busana}

Dari hasil penelitian peserta kursus menjahit diajarkan cara Mengambar busana dalam pembuatan sebuah busana sangatlah penting karena dalam proses menggambar busana diuraikan detail bagian-bagian busana sehingga dapat diketahui seperti apa pola yang akan dibuat dan bagaimana teknik menjahitnya. Menggambar busana harus dengan baik dan proporsional sehingga gambaran desain dapat dibaca dengan baik. Baik itu letak bahu, pinggang, pinggul, lutut, siku serta busana harus dibuat dengan jelas dan tepat dan memudahkan dalam membaca desain busana nantinya.

\section{Mengukur tubuh pelanggan sesuai SOP}

Dari hasil penelitian peserta kursus menjahit diajarkan cara Mengukur tubuh pelanggan, Mengukur tubuh pelanggan adalah faktor penting dalam menentukan subuah hasil benduk dari pola dan busana yang dibuat.. proses menentukan mengukur tubuh pada pelanggan yang digunakan untuk suatu busana dengan mengukur tubuh. Mengukur tubuh tidak bisah dilakukan sendiri tetapi harus dilakukan oleh orang lain contoh: Penjahit mengukur ukuran tubuh pelanggan.

\section{Mengambar pola dasar}

Dari hasil penelitian peserta kursus menjahit diajarkan cara Mengambar pola dasar merupakan pola baju yang meliputi ukuran bagian bahu sampai pinggang. Pola ini merupakan pola dasar baju. Biasanya pola ini terdiri dari 
bagian depan dan belakang pola ini merupakan yang sering mereka lakukan ketika mengikuti kursus menjahit.

\section{Keuntungan fnansial}

Dari hasil penelitian peserta kursus menjahit membuka usaha kecilkecilan yaitu menjahit pakaiaan bahkan mereka sudah bisah memasarkan hasil jahitan mereka sendiri walaupun banyak diantara mereka belum mau memasarkan hasil jahitan mereka diluar Desa Paris dengan alasan bahwa mereka takut hasil yang mereka buat tidak disukai oleh pelanggan diluar Desa Paris.

Implementasi kompetensi menjahit yang dilakukan oleh lulusan dalam aspek perubahan taraf hidup ialah lulusan memiliki pekerjaan berupa usaha menjahit pakaian dan usaha berbisnis memaklon pakaian dengan perusahaan yang bergerak dibidang industri menjahit pakaian yang pada akhirnya lulusan pun memperoleh pendapatan dalam menjalani usaha tersebut. Selain itu, untuk pendidikan lebih lanjut yang diperoleh lulusan ialah berupa penambahan ilmu pengetahuan berupa peroleh keterampilan menjahit yang dimiliki oleh lulusan serta penampilan sehari- hari lulusan yang menjadi memiliki kegiatan dalam kehidupan sehari-harinya berupa memiliki usaha menjahit pakaian yang mereka kelola sendiri.

Dalam aspek berbagi ilmu pengetahuan,diketahui bahwa pada umumnya lulusan belum terlalu memikirkan atau membutuhkan rekan kerja dalam melakukan kegiatan usaha menjahit yang mereka kelola. Untuk saat ini mereka masih merasa sanggup untuk melakukan kegiatan usaha menjahit dengan hanya dikelola oleh mereka sendiri. Pada aspek partisipasi dalam pembangunan, dapat disimpulkan lulusan memberikan partisipasi kepada lingkungan msayarakat sekitarnya berupa menyediakan jasa menjahit pakaian dan berbagi sedikit lahan pekerjaan untuk masyarakat sekitar meskipun sifatnya hanya sementara.

Upaya Pemerintah Desa Paris dalam mempersiapkan lulusan memasuki lapangan kerja dalam aspek perencanaan, pengelola melakukan identifikasi kebutuhan dengan menyesuaikan kembali kurikulum yang diberikan oleh Direktorat Pembinaan Kursus dan Kelembagaan dengan metoda pengajaran yang 
dilaksanakan di Desa Paris serta melakukan observasi dan penyesuaian dengan apa yang dibutuhkan oleh lingkungan pasar dalam hal kegiatan usaha menjahit pakaian. Dalam hal indentifikasi terhadap lulusan, lembaga pun melakukan observasi berupa wawancara guna mengetahui alasan dan tujuan lulusan dalam mengikuti kegiatan kursus menjahit sehingga lembaga dapat menentukan bagaimana program kursus menjahit yang sesuai untuk diikuti oleh lulusan. Untuk penyusunan program kegiatan kursus menjahit, lembaga memiliki dua tujuan utama yaitu yaitu untuk mencapai kemandirian lulusan dan mempersiapkan lulusan memasuki lapangan kerja.

\section{SIMPULAN}

Berdasarkan uraian hasil penelitian dan pembahasan, maka peneliti dapat menarik kesimpulan bahwa kompotensi yang diperoleh lulusan kursus menjahit di Desa Paris setelah mengikuti kegiatan menjahit ialah tercapainya pengetahuan menjahit yang diperoleh lulusan berupa krisis lulusan dalam mengikuti program kursus menjahit, kapabilitas strategis dan pengetahuan bisnis yang diperoleh lulusan dalam mengikuti program kursus menjahit. Untuk aspek keterampilan menjahit lulusan telah memiliki keterampilan menjahit yang mencakup fleksibilitas dalam menjahit pakaian, menggunakan keterampilan menjahitnya sesuai dengan berkepentingan dengan efektivitas kegiatan yang akan dilaksanakan, dan lulusan pun memiliki pengaruh yang baik dalam pengembangkan usaha menjahit pakaian di lingkungan masyarakat sekitarnya. Pada aspek sikap dan perilaku lulusan, lulusan kurang bisa memotivasi lingkungan masyarakat sekitarnya untuk mengikuti program kursus menjahit.

Namun disamping itu dalam hal membawa serta orang dengan berkepentingan dengan hasil, lulusan tidak terlalu kesulitan dalam menyesuaikan keterampilan menjahit yang ia peroleh dengan pekerjaan yang akan mereka jalani. Dan dalam hal membawa serta orang dengan pengaruh, pengaruh yang diberikan lulusan untuk lingkungan masyarakat sekitarnya berupa kemudahan masyarakat dalam memperoleh jasa menjahit pakaian serta adanya sedikit lahan pekerjaan baru yaitu membantu lulusan dalam menjalani pakaian meskipun hal ini sifatnya hanya sementara. 


\section{DAFTARPUSTAKA}

Abdulhak, I. (2000). Strategi Membangun Motivasi Pembelajaran Orang Dewasa. Bandung: Andira

Andi Prastowo. (2012). Panduan Kreatif Membuat Bahan Ajar Inovatif. Yogyakarta: Diva Press.

Badu, Ruslin. (2017). Reaktualisasi pendidikan luar sekolah. Nilai Budaya Komunitas Bajo, 50-51.

Hatimah, Ihat \& Sadri. 2014. Pembelajaran Berwawasan Kemasyarakatan. Jakarta: Universitas Terbuka

Hosio, J.E., 2007. Kebijakan Publik \& Desentralisasi: Esai-esai dari Sorong. Yogyakarta : Laksbang Yogyakarta

Hosio, JE. 2007. Kebijakan Publik dan Desentralisasi. Laksbang. Yogyakarta. Indah Apriyani, 1201412002 (2017) Pemberdayaan Penyandang Cacat Melalui Pelatihan Menjahit Di Loka Bina Karya Kabupaten Tegal. Under Graduates thesis, Universitas Negeri Semarang.

Jihad Asep \& Abdul haris.2012.Evaluasi Pembelajaran. Yogyakarta : Multi Presindo

Jones, Sue Jenkyn. Fashion Design. Laurence King Publishing. 2005 Komalasari

Kokom. 2010. Pembelajaran Kontekstual: Konsep dan Aplikasi. Refika Aditama. Bandung.

Komalasari, Kokom. 2013. Pembelajaran Kontekstul : Konsep dan Aplikasi. Bandung : PT Refika Adiatama

Kotler, Philip, dan Amstrong, 2001. Prinsip-Prinsip Manajemen, Jilid 1. Edisi Kedelapan Alih Bahasa Oleh Damos Sihombing, MBA., Jakarta: Erlangga

Latifa, Tami (2014) manfaat hasil belajar keterampilan menjahit tailor sebagai kesiapan magang di tailor. S1 thesis, Universitas Pendidikan Indonesia.

Mathis R.L dan Jackson J.H, 2002. Manajemen Sumber Daya Manusia, Jakarta: Salemba Empat.

Rahmat, a. (2020). Belajar dari alam biluhu model pembeajaran sentra bahasa alam pada taman kanak-kanak mmelalui pendekatan saintifik berbasis kawasan teluk tomini. Kota gorontalo: ideas publishing. 
Suratmo, F, Gunawan. 2004. Analisis Mengenai Dampak Lingkungan. Yogyakarta : Gadjah Mada University Press.

Tika Sukmawati (2018) upaya lkp lucky dalam meningkatkan keterampilan melalui program kursus menjahit bagi kalangan perempuan di lkp lucky desa tanimulya kec. Ngamprah kab. Bandung barat, IKIP Siliwangi, Cimahi, West Java Indonesia, 